\title{
THE
}

2-15-1993

\section{Methane and Carbon Monoxide Production, Oxidation, and Turnover Times in the Caribbean Sea as Influenced by the Orinoco River}

Ronald D. Jones

José A. Amador

University of Rhode Island, jam7740u@uri.edu

Follow this and additional works at: https://digitalcommons.uri.edu/nrs_facpubs

Terms of Use

All rights reserved under copyright.

\section{Citation/Publisher Attribution}

Jones, R. D., and J. A. Amador (1993), Methane and carbon monoxide production, oxidation, and turnover times in the Caribbean Sea as influenced by the Orinoco River, J. Geophys. Res., 98(C2), 2353-2359, doi:10.1029/92JC02769.

Available at: http://dx.doi.org/10.1029/92JC02769

This Article is brought to you for free and open access by the Natural Resources Science at DigitalCommons@URI. It has been accepted for inclusion in Natural Resources Science Faculty Publications by an authorized administrator of DigitalCommons@URI. For more information, please contact digitalcommons-group@uri.edu. 


\title{
Methane and Carbon Monoxide Production, Oxidation, and Turnover Times in the Caribbean Sea as Influenced by the Orinoco River
}

\author{
Ronald D. Jones and José A. Amador \\ Department of Biological Sciences and Drinking Water Research Center, \\ Florida International University, Miami
}

\begin{abstract}
The surface distribution of $\mathrm{CH}_{4}$, photoproduction capacity of seawater for $\mathrm{CO}$, and $\mathrm{CH}_{4}$ and $\mathrm{CO}$ microbial oxidation rates and turnover times were determined for the surface waters of the southeastern Caribbean Sea and Gulf of Paria as affected by the Orinoco River. Measurements were made during the spring (low river flow) and the fall (high river flow) in order to determine the influence of Orinoco River discharge on these parameters. Methane concentrations were generally lower in the fall than in the spring. Low $\mathrm{CH}_{4}$ oxidation rates and similar surface distributions were observed during both seasons. Methane oxidation in the river plume was significantly higher in the fall. Potential CO photoproduction and $\mathrm{CO}$ oxidation rates were generally higher during the fall. Possible effects of the Orinoco River on potential CO photoproduction capacity were observed as far as Puerto Rico. Turnover times for $\mathrm{CH}_{4}$ were in the order of years, whereas $\mathrm{CO}$ turnover times were in the order of hours. The Orinoco River has a significant impact on the consumption of $\mathrm{CO}$ and $\mathrm{CH}_{4}$ and the photoproduction of $\mathrm{CO}$ in the southeastern Caribbean Sea, presumably resulting from inputs of riverine carbon and nutrients.
\end{abstract}

\section{INTRODUCTION}

The Orinoco River contributes approximately $86 \times 10^{6}$ tons of suspended material per year to the Caribbean Sea through its estuarine-deltaic system [Salazar, 1989]. Maximum water flow occurs in August, when precipitation is highest $(127 \mathrm{~mm})$ and minimum flow occurs in March, when precipitation is lowest $(19 \mathrm{~mm})$, with an average flow of $34 \times$ $10^{3} \mathrm{~m}^{3} \mathrm{~s}^{-1}$ [Salazar, 1989]. Measurements of pigment concentration in the Caribbean Sea show that the influence of the Orinoco River on the Caribbean Sea during the high flow season reaches Puerto Rico [Müller-Karger and Varela, 1988]. Thus, the Caribbean Sea/Orinoco River system presents an opportunity to study the effects of terrestrial freshwater inputs on marine biological and chemical processes, particularly those affecting carbon and nutrient cycling.

Rivers often contain high levels of $\mathrm{CH}_{4}$ resulting from both natural [de Angelis and Lilley, 1987; Wilkness et al., 1978] and anthropogenic [Brooks and Sackett, 1973; Butler et al., 1987] sources. For example, de Angelis and Lilley [1987] observed high natural levels of $\mathrm{CH}_{4}$ in undisturbed forest streams and rivers from the Oregon coast. Furthermore, mixing between high $\mathrm{CH}_{4}$-containing river water and low $\mathrm{CH}_{4}$-containing seawater end-members appeared to control $\mathrm{CH}_{4}$ concentrations in estuaries [de Angelis and Lilley, 1987].

Rivers also contain supersaturated concentrations of $\mathrm{CO}$ [Butler et al., 1987], but their contribution to $\mathrm{CO}$ levels found in estuarine and sea waters is unclear. The largest source of $\mathrm{CO}$ in surface waters appears to be abiotic photooxidation of dissolved organic material [Wilson et al., 1970; Conrad and Seiler, 1980; Conrad et al., 1982; Redden, 1983]. Consumption of $\mathrm{CO}$ is primarily a bacterial oxidation process [Conrad et al., 1982].

Copyright 1993 by the American Geophysical Union.

Paper number $92 \mathrm{JC} 02769$.

0148-0227/93/92JC-02769\$05.00
Methane concentration and $\mathrm{CO}$ production, and oxidation and turnover times for these gases were measured in the surface waters of the southeastern Caribbean Sea, the Gulf of Paria, and the Orinoco River in order to determine the influence of river inputs on these parameters in seawater.

\section{Materials and Methods}

\section{Water Samples}

Surface water samples were collected during two cruises to the southeastern Caribbean Sea and the Orinoco River in Venezuela during April and October 1988 (Figure 1). Additional cruise details are presented in the paper by Bonilla et al. [this issue]. Water samples were collected using a teflonlined bow pumping system connected to the inlet of an automated gas chromatographic/stripping system (described below). Samples for $\mathrm{CH}_{4}$ and $\mathrm{CO}$ concentration measurements were collected automatically every $30 \mathrm{~min}$ while the ship was underway and every 60 min when the ship was on station. The fixed sampling stations for both the spring and fall cruises are shown in Figure 1. Samples for determination of microbial activities were collected using the same pumping system and placed in $500-\mathrm{mL}$ polyethylene bottles. All microbiological and photochemical assays were conducted within 4 hours of sample collection.

\section{Methane and Carbon Monoxide Concentration}

Methane and CO concentrations were measured from the same water sample using an automated version of the gas chromatograph/stripper described by Redden [1983] and Butler et al. [1987]. Two hundred and fifty milliliters of sample were automatically drawn from the bow pumping system into an evacuated stripping flask (500 $\mathrm{mL})$ and stripped for 10 min with purified helium flowing at $100 \mathrm{~mL}$ $\min ^{-1}$ through a scintered glass disk. The stripped gases and the helium carrier were passed through traps containing Drierite (10/20 mesh) and Ascarite (8/20 mesh) and onto a 


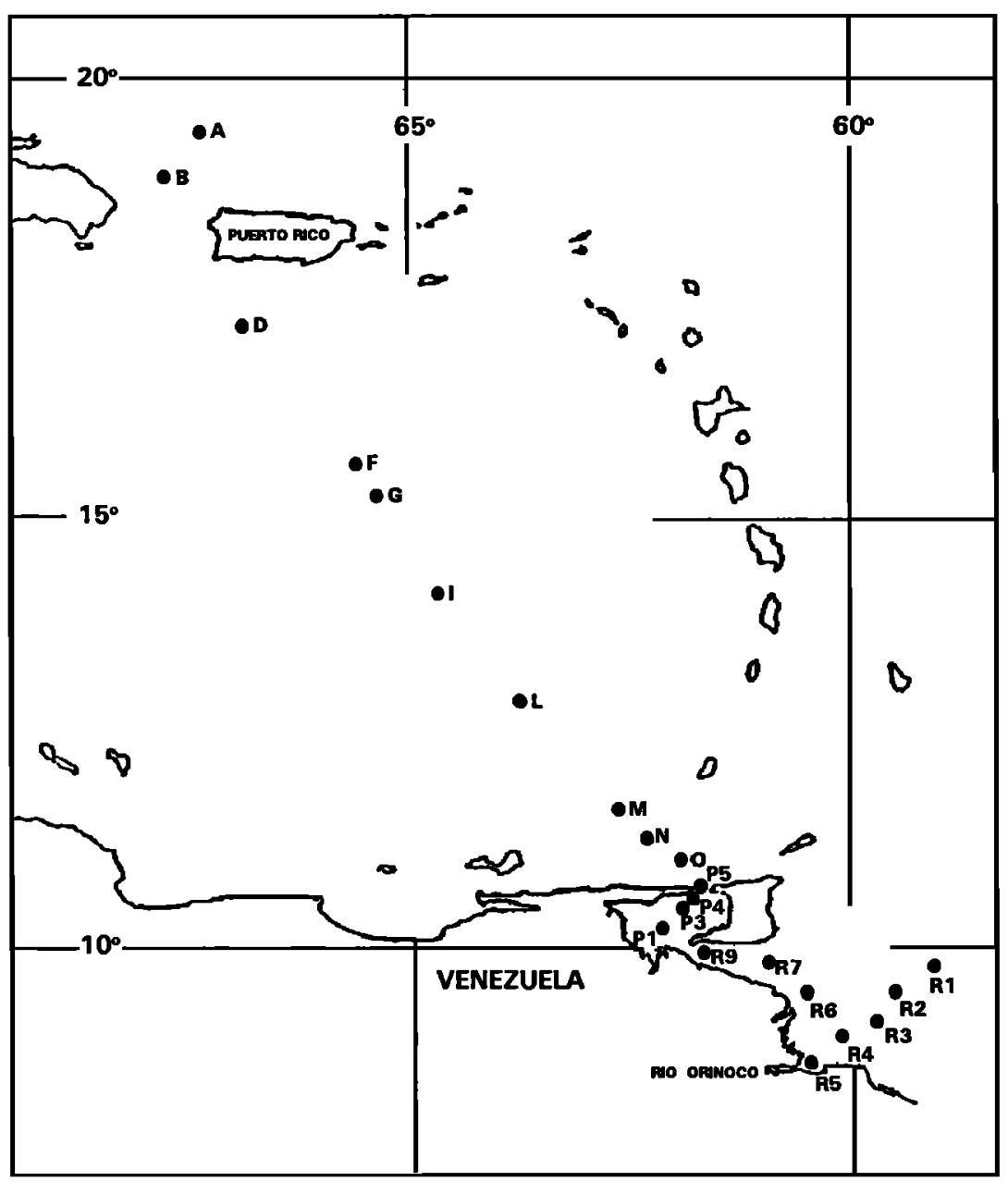

Fig. 1. Location of sampling stations for spring and fall cruises.

liquid nitrogen-cooled molecular sieve trap (MS-5A) that retained and partially separated the $\mathrm{CO}$ and $\mathrm{CH}_{4}$. The molecular sieve trap was removed from the liquid nitrogen bath and heated to $200^{\circ} \mathrm{C}$. The carrier gas containing the $\mathrm{CO}$ and $\mathrm{CH}_{4}$ was sent to the gas chromatograph (model HP5890, fitted with a MS-5A molecular sieve, $60 / 80$ mesh, column, $0.318 \mathrm{~cm}$ ID $\times 2 \mathrm{~m}$ long), mixed with a stream of $\mathrm{H}_{2}$ gas, and the resulting mixture passed over a heated $\left(320^{\circ} \mathrm{C}\right) \mathrm{Ni}$ catalyst to reduce $\mathrm{CO}$ to $\mathrm{CH}_{4}$. Methane and $\mathrm{CO}$ were quantified using a flame ionization detector. Additional details of the gas chromatograph/stripping system configuration and standardization procedures can be found in Jones [1991].

\section{Methane and Carbon Monoxide Oxidation}

Methane and $\mathrm{CO}$ oxidation rates were measured using ${ }^{14} \mathrm{C}$-labeled gases, as described by Jones and Morita [1983a, b] and Jones et al. [1984]. Water samples $(25 \mathrm{~mL})$ were placed in $60-\mathrm{mL}$ serum bottles, degassed for $8 \mathrm{~min}$ with activated carbon-filtered air, sealed with serum stoppers, and $0.5 \mathrm{~mL}$ of ${ }^{14} \mathrm{CO}$ diluted in nitrogen $\left(0.5 \mu \mathrm{Ci} \mathrm{mL}{ }^{-1}\right.$; 56 $\mathrm{mCi} \mathrm{mmol}^{-1}$; Amersham Corp., Arlington Heights, Illinois) or $1.0 \mathrm{~mL}$ of ${ }^{14} \mathrm{CH}_{4}$ diluted in nitrogen $\left(1.0 \mu \mathrm{Ci} \mathrm{mL}{ }^{-1} ; 59\right.$ $\mathrm{mCi} \mathrm{mmol}^{-1}$; Amersham) was injected into the headspace. Degassing with filtered air reduced dissolved $\mathrm{CH}_{4}$ and $\mathrm{CO}$ concentrations so they represented $<0.05 \%$ of the labeled substrate, thus assuring no discernible isotope dilution ef- fects. All bottles were prepared in triplicate and acidified controls were incubated along with samples from each series. Bottles were incubated in the dark for either 12 hours $\left({ }^{14} \mathrm{CO}\right)$ or 24 hours $\left({ }^{14} \mathrm{CH}_{4}\right)$ at $26^{\circ} \mathrm{C}$. The reaction was terminated by injection of $1.0 \mathrm{~mL}$ of $5 N \mathrm{NaOH}$. Bottles were then transported to the laboratory where ${ }^{14} \mathrm{CO}_{2}$ was released, trapped, and assayed using the methods described by Griffiths et al. [1982]. The equilibrium concentrations of ${ }^{14} \mathrm{CH}_{4}$ and ${ }^{14} \mathrm{CO}$ in solution were determined by multiplying the Bunsen solubility coefficient (Schmidt [1979] for CO; Yamamoto et al. [1976] for $\mathrm{CH}_{4}$ ). Both salinity and temperature effects on solubility were taken into account when calculating oxidation rates. $\mathrm{CH}_{4}$ and $\mathrm{CO}$ oxidation rates were normalized to rates at $\mathrm{a} \mathrm{CH}_{4}$ concentration of $11.93 \mathrm{nM}$ and a $\mathrm{CO}$ concentration of $2.23 \mathrm{nM}$, thus allowing comparison with previous work. No significant incorporation of ${ }^{14} \mathrm{C}$ into cellular material was detected in any of the ${ }^{14} \mathrm{CO}$ samples and only samples from stations R3, R4 and R5 demonstrated significant ${ }^{14} \mathrm{C}$ incorporation from ${ }^{14} \mathrm{CH}_{4}$. These samples incorporated between 3 and $5 \%$ of the label. Since incorporation was so limited only ${ }^{14} \mathrm{CO}_{2}$ production was used in both $\mathrm{CH}_{4}$ and $\mathrm{CO}$ oxidation rate determinations.

\section{Potential Photoproduction Capacity for Carbon Monoxide}

Potential photoproduction capacity of the water for $\mathrm{CO}$ was determined using surface water samples. The water 
TABLE 1. Methane Concentrations, Oxidation Rates, and Turnover Times

\begin{tabular}{|c|c|c|c|c|c|c|}
\hline \multirow[b]{2}{*}{ Station } & \multicolumn{3}{|c|}{ Spring } & \multicolumn{3}{|c|}{ Fall } \\
\hline & $\begin{array}{c}\text { Ambient } \\
\text { Concentration, } \\
\text { nM }\end{array}$ & $\begin{array}{c}\text { Oxidation } \\
\text { Rate, } \\
\text { pmol } L^{-1} h^{-1}\end{array}$ & $\begin{array}{l}\text { Turnover } \\
\text { Time, } \\
\text { years }\end{array}$ & $\begin{array}{c}\text { Ambient } \\
\text { Concentration, } \\
\mathbf{n M}\end{array}$ & $\begin{array}{c}\text { Oxidation } \\
\text { Rate } \\
\text { pmol } \mathbf{L}^{-1} \mathbf{h}^{-1}\end{array}$ & $\begin{array}{c}\text { Turnover } \\
\text { Time, } \\
\text { years }\end{array}$ \\
\hline A & - & - & - & 2.7 & 0.04 & 38.8 \\
\hline B & 1.6 & 0.04 & 37.3 & - & - & - \\
\hline D & - & - & - & 2.8 & 0.04 & 31.5 \\
\hline $\mathbf{F}$ & 1.7 & 0.05 & 30.1 & - & - & - \\
\hline G & - & - & - & 3.3 & 0.02 & 63.6 \\
\hline $\bar{I}$ & 2.0 & 0.30 & 4.6 & - & - & - \\
\hline L & - & - & - & 3.6 & 0.02 & 71.5 \\
\hline$\overline{\mathbf{M}}$ & 2.1 & 0.18 & 7.4 & 12 & 0.02 & 56.1 \\
\hline $\mathbf{N}$ & 5.2 & 0.15 & 8.8 & - & - & - \\
\hline 0 & - & - & - & 33 & 0.40 & 3.4 \\
\hline P5 & 18 & 0.33 & 4.1 & 36 & 0.27 & 5.0 \\
\hline P4 & - & - & - & 31 & 0.24 & 5.8 \\
\hline P3 & 40 & 0.38 & 3.6 & 34 & 0.55 & 2.5 \\
\hline P1 & 66 & 0.85 & 1.6 & 37 & 0.34 & 4.0 \\
\hline R9 & 176 & 3.47 & 0.4 & - & - & - \\
\hline R7 & 39 & 0.45 & 3.0 & 48 & 0.47 & 2.9 \\
\hline R6 & 68 & 0.36 & 3.8 & 61 & 0.94 & 1.5 \\
\hline R5 & 103 & 2.23 & 0.6 & 13 & 168.7 & 0.007 \\
\hline R4 & 138 & - & - & 25 & 119.7 & 0.008 \\
\hline R3 & 37 & 6.63 & 0.2 & 9.0 & 2.27 & 0.06 \\
\hline R2 & 27 & - & - & 3.0 & 0.19 & 7.2 \\
\hline R1 & 46 & 0.24 & 5.7 & 3.2 & 0.13 & 10.4 \\
\hline
\end{tabular}

Station designations refer to Figure 1. Oxidation rates normalized to a concentration of $11.93 \mathrm{nM}$. Turnover time is defined as the inverse of the first-order rate constant.

samples $(160 \mathrm{~mL})$ were drawn into quartz tubes $(30 \mathrm{~cm}$ long $\times 2.6 \mathrm{~cm}$ diameter) fitted with polypropylene valves and syringe plungers covered with teflon. The tubes containing the water were placed in a circulating water bath and irradiated in full sunlight on the deck of the ship between 1000 and 1500 LT. Samples wrapped with aluminum foil to prevent light penetration were exposed to the same conditions as controls (time-zero blanks). Carbon monoxide concentrations were measured as described above. Total solar irradiance was measured using a radiometer fitted with a bandpass filter that limits the spectral response of the photocell to wavelengths between 300 and $700 \mathrm{~nm}$, and all samples were normalized to $1000 \mathrm{Wh} \mathrm{m}^{-2}$ irradiance.

\section{REsults AND Discussion}

\section{Methane}

Surface concentrations of $\mathrm{CH}_{4}$ during the spring ranged from less than $2 \mathrm{nM}$ in the middle of the Caribbean Sea to 138 nM (station R4) near the mouth of the Orinoco (Table 1 and Figure $2 a$ ). Methane concentration decreased sharply with distance from the Orinoco River on a northeasterly direction towards the Atlantic Ocean, where surface concentrations of $\mathrm{CH}_{4}$ were on the order of $45 \mathrm{nM}$. The highest concentrations of $\mathrm{CH}_{4}$ were observed near the Serpents Mouth (station R9), at the southern entrance to the Gulf of Paria, and decreased sharply towards the Caribbean Sea (Table 1 and Figure $2 a$ ).

During the fall, surface $\mathrm{CH}_{4}$ concentrations had a narrower range, from $3.3 \mathrm{nM}$ in the central Caribbean to $61 \mathrm{nM}$ northeast of the mouth of the Orinoco near the coast (Figure $2 b$ ). The area of highest $\mathrm{CH}_{4}$ concentration near the mouth of the Orinoco during the spring was found further out to sea and to the northwest during the fall. Changes in $\mathrm{CH}_{4}$ concentration with distance from the Orinoco were less abrupt during the fall, with a fairly even surface distribution in the coastal area from the mouth of the Orinoco to the Gulf of Paria. There was little difference in the concentration of $\mathrm{CH}_{4}$ between the Atlantic Ocean and the Caribbean Sea. However, these differences were of sufficient magnitude that the influence of the Orinoco was detected as far as Puerto Rico in the fall (Table 1) (see paper by Moore and Todd [this issue]).

The range of surface $\mathrm{CH}_{4}$ concentrations was generally narrower during the fall than in the spring; however, the area of the southeastern Caribbean Sea with elevated concentrations was much larger (Figure 2) in the fall. Lower $\mathrm{CH}_{4}$ concentrations during the fall may be due to dilution of the riverine source resulting from increased river flow, particularly in the estuarine-deltaic area of the Orinoco. These results indicate that the delta area and Gulf of Paria are potential sources of $\mathrm{CH}_{4}$, in addition to the Orinoco River itself. Similar seasonal effects on distribution of $\mathrm{CH}_{4}$ concentration concurrent with changes in river flow have been observed in Yaquina Bay, Oregon [Butler et al., 1987]. Alternatively, these differences may be accounted for by seasonal differences in $\mathrm{CH}_{4}$ oxidation rates. Methane oxidation rates were extremely low during both the spring and fall, with similar surface distributions (Table 1). However, significantly higher $\mathrm{CH}_{4}$ oxidation rates were observed during the fall in the Orinoco River plume. The higher rates of $\mathrm{CH}_{4}$ oxidation may have contributed to the decrease in surface $\mathrm{CH}_{4}$ concentration in the fall, particularly in the area of the river plume (Northwest to the Gulf of Paria). Higher rates of $\mathrm{CH}_{4}$ oxidation may result from the large input of nutrients and sediments from the Orinoco River during the fall [Bonilla et al., this issue]. Methane oxidation has been shown to increase with increasing general microbial activity and ammonia concentration [Griffiths et al., 1982]. 


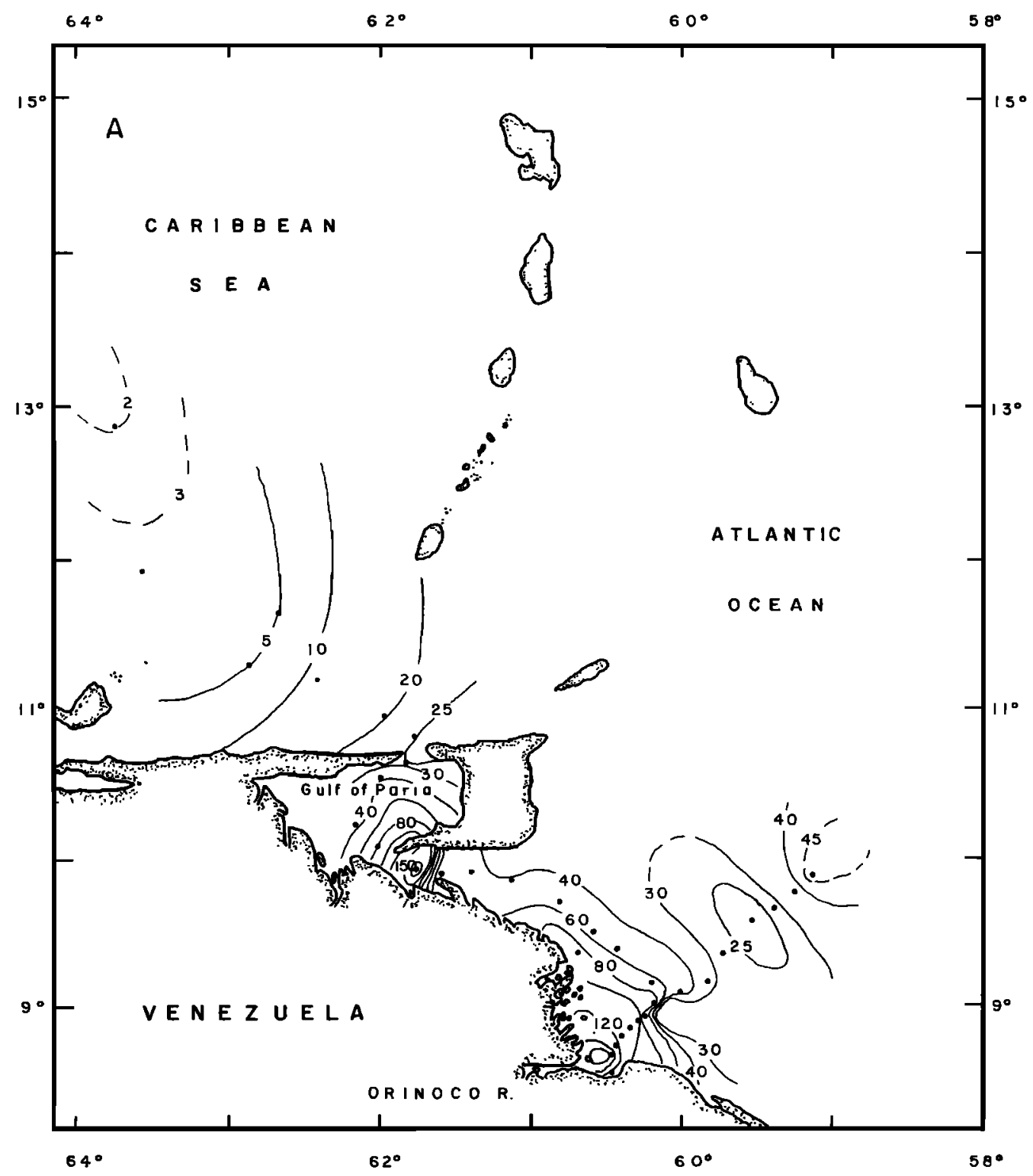

Fig. 2. Distribution of surface $\mathrm{CH}_{4}$ concentrations during the $(a)$ spring and $(b)$ fall in the Caribbean Sea and Orinoco River. Sampling was continuous while the ship was underway; not all sample collection points are indicated.

Turnover times for $\mathrm{CH}_{4}$ were in the order of years and were generally longer in the fall than in the spring (Table 1). Turnover times were shortest near the mouth of the Orinoco during both seasons, with a low value of 0.005 yr (about 2 days) at station R5 during the fall. The highest turnover times were observed in the Caribbean Sea during the fall (Table 1). The $\mathrm{CH}_{4}$ turnover times were comparable to those observed previously in the Caribbean Sea by Ward [1987].

\section{Carbon Monoxide}

Surface CO concentrations ranged from $0.9 \mathrm{nM}$ near the Mona Passage (station B) to $4.9 \mathrm{nM}$ near the mouth of the Orinoco River (station R5) during the spring (Table 2). In the fall surface $\mathrm{CO}$ concentrations were significantly higher at stations $R 1$ and $R 2$ with values of $31.6 \mathrm{nM}$ and $21.3 \mathrm{nM}$, respectively (Table 2 and Figure 1). Due to the nonconservative nature of $\mathrm{CO}$ in surface waters, it is difficult to interpret this data without additional information. Factors such as photoproduction capacity, light intensity and microbial oxidation (turnover times) can cause surface $\mathrm{CO}$ concentrations to vary 1 to 2 orders of magnitude over a 24-hour period [Conrad et al., 1982; Butler et al., 1987; Jones, 1991]. Therefore, values reported in Table 2 indicate only the concentration at the time of sample collection.

Potential photoproduction capacity for $\mathrm{CO}$ during the spring was lowest in the vicinity of Mona Passage (station B) and increased in the vicinity of the Orinoco River and Gulf of Paria (Table 2). The highest values for $\mathrm{CO}$ photoproduction capacity were observed in the Gulf of Paria $\left(36.6 \mathrm{nmol} \mathrm{L}^{-1}\right.$ $h^{-1}$, station P3) and on a transect northeast of the mouth of the Orinoco River (43.5 nmol L ${ }^{-1} \mathrm{~h}^{-1}$, station R1).

Values for $\mathrm{CO}$ potential photoproduction capacity during the fall ranged from $22.8 \mathrm{nmol} \mathrm{L}{ }^{-1} h^{-1}$ near Mona Passage (station A) increasing with proximity to the Orinoco River to $88.3 \mathrm{nmol} \mathrm{L}{ }^{-1} \mathrm{~h}^{-1}$ at station $\mathrm{R} 3$ near the mouth of the Orinoco. Potential photoproduction capacity for $\mathrm{CO}$ was 


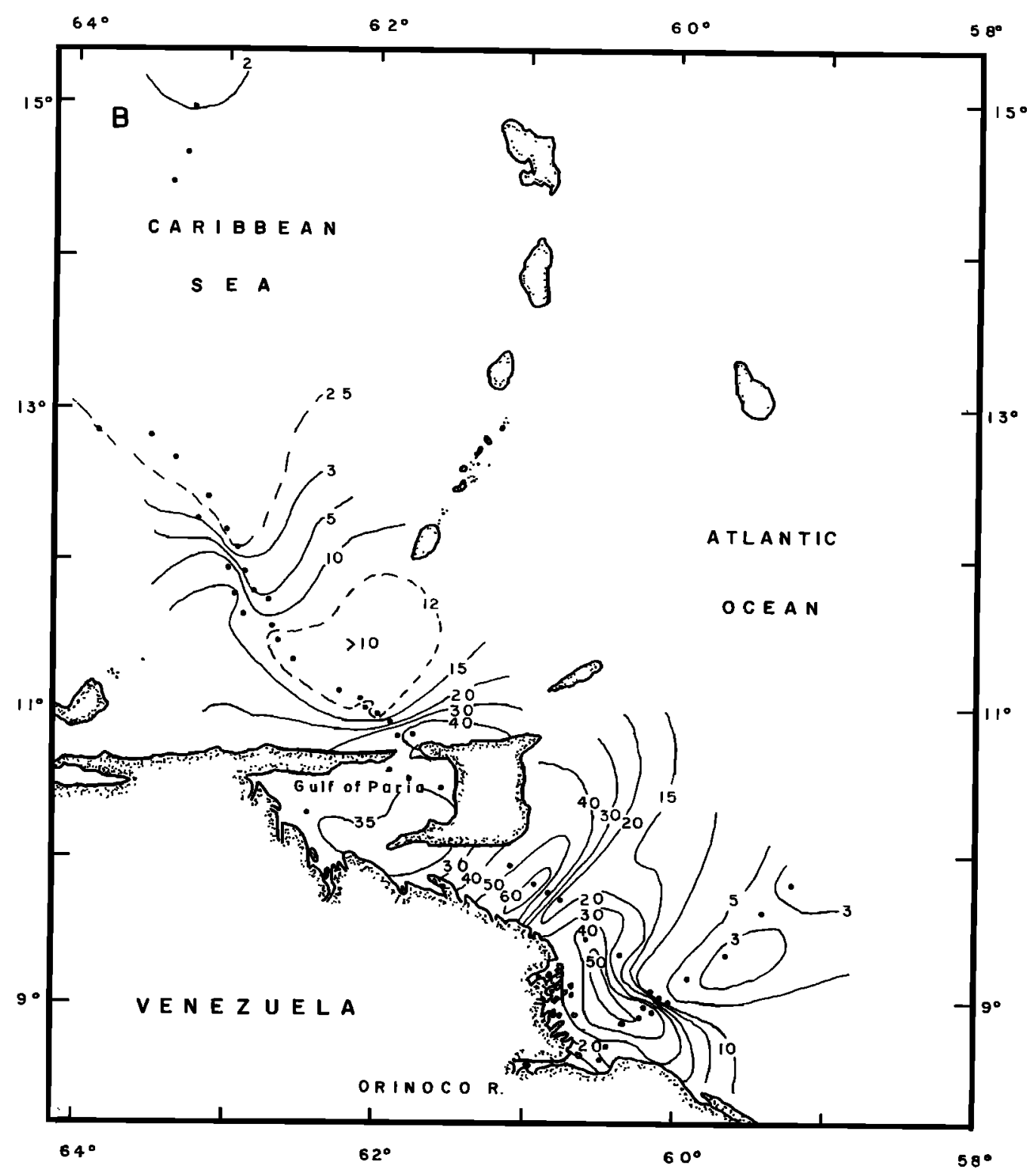

Fig. 2. (continued)

generally higher in the fall than in the spring, with higher values observed particularly in the northern and central Caribbean Sea and the mouth of the Orinoco River.

The Orinoco River waters appear to affect CO photoproduction as far as the Mona Passage near Puerto Rico during the fall (Table 2). Higher concentrations of dissolved organic matter are observed in the Caribbean Sea during the fall than in the spring, evidenced by higher optical densities of the water during this season [Zika et al., this issue], possibly increasing the concentration of precursor molecules for $\mathrm{CO}$ photoproduction. Higher microbial activity during the fall may also contribute to higher $\mathrm{CO}$ photoproduction rates by increasing the concentration of humic substances, know to contain carbonyl moieties, that are precursors for CO photoproduction [Redden, 1983; Mopper et al., 1991].

Carbon monoxide oxidation rates during the spring followed a pattern similar to that for $\mathrm{CO}$ photoproduction capacity. The rates were lowest near the Mona Passage (station B) (25 pmol L-1 $\mathrm{h}^{-1}$ ), increased with proximity to the Orinoco River, and were highest at station R5 near the mouth of the river (976 pmol $\mathrm{L}^{-1} \mathrm{~h}^{-1}$ ) (Table 2). Intermediate values of $\mathrm{CO}$ oxidation were observed in the Gulf of Paria (118-143 pmol L-1 $\mathrm{h}^{-1}$ ).

Carbon monoxide oxidation rates were generally higher in the fall, particularly in the Caribbean Sea and the Gulf of Paria (Table 2). However, CO oxidation rates were lower in the vicinity of the Orinoco River in the fall than in the spring, with a maximum value of $663 \mathrm{pmol} \mathrm{L} \mathrm{L}^{-1} \mathrm{~h}^{-1}$ at station R4.

Carbon monoxide oxidation in the Caribbean Sea during the spring may be limited by nutrient availability [Bonilla et al., this issue]. This limitation could possibly be removed with the influx of higher concentrations of nutrients transported by the Orinoco River during the fall, resulting in increased microbial $\mathrm{CO}$ oxidation rates. The lower $\mathrm{CO}$ oxidation rates observed during the fall near the mouth of the Orinoco River are puzzling. Carbon monoxide oxidizing bacteria may be inhibited by the high concentrations of $\mathrm{CO}$ in the water resulting from higher photoproduction of $\mathrm{CO}$ in 
TABLE 2. Carbon Monoxide Concentrations, Oxidation Rates, Turnover Times, and Potential Photoproduction Capacities

\begin{tabular}{|c|c|c|c|c|c|c|c|c|}
\hline \multirow[b]{2}{*}{ Station } & \multicolumn{4}{|c|}{ Spring } & \multicolumn{4}{|c|}{ Fall } \\
\hline & $\begin{array}{c}\text { Ambient } \\
\text { Concentration, } \\
\text { nM }\end{array}$ & $\begin{array}{c}\text { Oxidation } \\
\text { Rate } \\
\text { pmol L L }^{-1} \mathbf{h}^{-1}\end{array}$ & $\begin{array}{l}\text { Turnover } \\
\text { Time, } \\
\text { hours }\end{array}$ & $\begin{array}{c}\text { Production, } \\
\text { nmol L } \\
h^{-1}\end{array}$ & $\begin{array}{c}\text { Ambient } \\
\text { Concentration, } \\
n \mathbf{n}\end{array}$ & $\begin{array}{c}\text { Oxidation } \\
\text { Rate, } \\
\text { pmol } \mathbf{L}^{-1} \mathbf{h}^{-1}\end{array}$ & $\begin{array}{l}\text { Turnover } \\
\text { Time, } \\
\text { hours }\end{array}$ & $\begin{array}{l}\text { Production, } \\
\text { nmol L L }^{-1} \\
h^{-1}\end{array}$ \\
\hline A & - & - & - & - & 1.7 & 20 & 98 & 22.8 \\
\hline B & 0.9 & 25 & 88 & 18.5 & - & - & - & - \\
\hline D & - & - & - & - & 1.2 & 88 & 25 & - \\
\hline $\mathbf{F}$ & 1.9 & 58 & 39 & 18.5 & - & - & $=$ & - \\
\hline $\mathbf{G}$ & - & - & - & - & 0.9 & 156 & 14 & 25.5 \\
\hline I & 1.2 & 66 & 34 & - & - & - & - & - \\
\hline $\mathbf{L}$ & - & - & - & - & 1.6 & 275 & 8 & - \\
\hline $\mathbf{M}$ & 0.9 & 42 & 53 & - & 2.7 & 292 & 8 & - \\
\hline $\mathbf{N}$ & 2.8 & 32 & 70 & - & - & - & - & - \\
\hline 0 & - & - & - & - & 0.7 & 372 & 6 & - \\
\hline P5 & 2.8 & 143 & 16 & 32.5 & 0.6 & 814 & 3 & - \\
\hline P4 & - & - & - & - & 6.1 & 636 & 4 & - \\
\hline P3 & 6.3 & 136 & 16 & 36.6 & 5.7 & 432 & 5 & - \\
\hline P1 & 2.4 & 118 & 19 & - & 2.8 & 313 & 7 & - \\
\hline R9 & 3.8 & 247 & 9 & 29.0 & - & - & - & - \\
\hline R7 & 2.5 & 159 & 14 & - & 1.0 & 365 & 6 & - \\
\hline R6 & 1.7 & 145 & 15 & - & 1.2 & 497 & 4 & - \\
\hline R5 & 4.9 & 976 & 2 & 19.1 & 0.7 & 540 & 4 & 63.6 \\
\hline R4 & 4.6 & - & - & - & 2.4 & 663 & 3 & 76.8 \\
\hline $\mathbf{R} 3$ & 4.1 & 342 & 7 & 23.7 & 0.7 & 602 & 4 & 88.3 \\
\hline R2 & 3.2 & - & - & - & 21.3 & 339 & 7 & 28.1 \\
\hline R1 & 2.3 & 21 & 108 & 43.5 & 31.6 & 366 & 6 & 22.9 \\
\hline
\end{tabular}

Station designations refer to Figure 1. Oxidation rates normalized to a concentration of $2.23 \mathrm{nM}$. Turnover time is defined as the inverse of the first-order rate constant. CO photoproduction capacities are normalized to $1000 \mathrm{Wh} \mathrm{m} \mathrm{m}^{-2}$ of total solar irradiance.

this area during the fall. Nitrifying bacteria and carboxydobacteria are both believed to have a role in oxidizing $\mathrm{CO}$ in the oceans [Conrad and Seiler, 1980], and high concentrations of $\mathrm{CO}$ are inhibitory of marine nitrifying bacteria [Jones and Morita, 1983a, b].

Turnover times for carbon monoxide were in the order of hours (Table 2). During the spring, turnover times in the Caribbean increased with distance from the mouth of the Orinoco, ranging from 2 hours at station R5 to 108 hours at station R1. Turnover times were generally lower during the fall, and ranged from 3 hours at station R4 near the mouth of the Orinoco River to 98 hours at station A north of Puerto Rico. Carbon monoxide turnover times were consistent with those observed in similar environments [Jones, 1991].

These results indicate that the Orinoco River and deltaic system may contribute large amounts of $\mathrm{CH}_{4}$ and precursor molecules for $\mathrm{CO}$ photoproduction, thus influencing the chemical and biological processes that control the concentration of these gases in the surface waters of the Caribbean Sea.

Acknowledgments. This work was supported by the National Science Foundation under grant OCE-8620249. Thanks are extended to Captain Robert Morgan and the crew of the R/V Columbus Iselin for their assistance.

\section{REFERENCES}

Bonilla, J., W. Senior, J. Bugden, O. Zafiriou, and R. Jones, Seasonal distribution of nutrients and primary productivity on the eastern continental shelf of Venezuela as influenced by the Orinoco River, J. Geophys. Res., this issue.

Brooks, J. M., and W. M. Sackett, Sources, sinks, and concentrations of light hydrocarbons in the Gulf of Mexico, J. Geophys. Res., 78, 5248-5258, 1973.

Butler, J. H., R. D. Jones, J. H. Garber, and L. I. Gordon, Seasonal distribution and turnover of reduced trace gases and hydroxylamine in Yaquina Bay, Oregon, Geochim. Cosmochim. Acta, 51, 697-706, 1987.

Conrad, R., and W. Seiler, Photooxidative production and microbial consumption of carbon monoxide in seawater, FEMS Microbiol. Lett., 9, 61-64, 1980.

Conrad, R., W. Seiler, G. Bunse, and H. Giehl, Carbon monoxide in seawater (Atlantic Ocean), J. Geophys. Res., 87, 8852-8893, 1982.

de Angelis, M. A., and M. D. Lilley, Methane in surface waters of Oregon estuaries and rivers, Limnol. Oceanogr., 32, 716-722, 1987.

Griffiths, R. P., B. A. Caldwell, J. D. Cline, W. A. Broich, and R. Y. Morita, Field observations of methane concentrations and oxidation rates in the southeastern Bering Sea, Appl. Environ. Microbiol., 44, 435-446, 1982.

Jones, R. D., Carbon monoxide and methane distribution and consumption in the photic zone of the Sargasso Sea, Deep Sea Res., 38, 625-635, 1991.

Jones, R. D., and R. Y. Morita, Effects of several nitrification inhibitors on carbon monoxide oxidation and methane oxidation by ammonium oxidizers, Can. J. Microbiol., 30, 276-279, $1983 a$.

Jones, R. D., and R. Y. Morita, Effects of various parameters on carbon monoxide oxidation by ammonium oxidizers, Can. $J$. Microbiol., 30, 894-899, $1983 b$.

Jones, R. D., R. Y. Morita, and R. P. Griffiths, Method for estimating chemolithotrophic ammonium oxidation using carbon monoxide oxidation, Mar. Ecol. Prog. Ser., 17, 259-269, 1984.

Moore, C. A., and J. F. Todd, Radium isotopes in the Orinoco Estuary and eastern Caribbean Sea, J. Geophys. Res., this issue. Mopper, K., X. Zhou, R. J. Kieber, D. J. Kieber, R. J. Sikorski, and R. D. Jones, Photochemical degradation of dissolved organic carbon and its impact on the oceanic carbon cycle, Nature, 353, 60-62, 1991.

Müller-Karger, F. E., and R. J. Varela, Variabilidad de la biomasa de fitoplancton en aguas superficiales del mar Caribe con el CZCS, EDIMAR FLASA, I71, 1-23, 1988.

Redden, G. D., Characteristics of photochemical production of carbon monoxide in seawater, M.S. thesis, Oregon State Univ., Corvallis, 1983.

Salazar, J. C., Condiciones hidrogeoquímicas de la región estuarinadeltaica del Orinoco durante el mes de noviembre de 1985, M.S. 
thesis, Inst. Oceanogr. Venezuela, Univ. de Oriente, Cumaná, 1989.

Schmidt, U., The solubility of carbon monoxide and hydrogen in water and sea-water at partial pressures of about $10^{-5}$ atmospheres, Tellus, 31, 68-74, 1979.

Ward, B. B., Kinetic studies on ammonia and methane oxidation by Nitrosococcus oceanus, Arch. Microbiol., 147, 126-133, 1987.

Wilkness, P. E., R. A. Lamontagne, R. E. Larson, and J. W Swinnerton, Atmospheric trace gases and land and sea breezes at the Sepik River coast of Papua New Guinea, J. Geophys. Res., 83, 3672-3674, 1978.

Wilson, D. F., J. W. Swinnerton, and R. A. Lamontagne, Production of carbon monoxide and gaseous hydrocarbons in seawater: relation to dissolved organic carbon, Science, 168, 577-579, 1970. Yamamoto, S., J. B. Alacauskas, and T. E. Crozier, Solubility of methane in distilled water and seawater, J. Chem. Eng. Data, 21, 78-80, 1976.

Zika, R. G., P. J. Milne, and O. C. Zafiriou, Photochemical studies of the eastern Caribbean: An introductory overview, J. Geophys. Res., this issue.

J. A. Amador and R. D. Jones, Department of Biological Sciences and Drinking Water Research Center, Florida International University, Miami, FL 33199.

(Received May 3, 1991;

revised April 2, 1992;

accepted April 12, 1992.) 